\title{
An exploration of synthetic biology: A preliminary Christian ethical assessment of the advantages and disadvantages of synthetic biology
}

\section{Author:}

Riaan A.L. Rheeder ${ }^{1}$

Affiliation:

${ }^{1}$ Faculty of Theology, Unit for the Development of Reformed Theology, NorthWest University, South Africa

\section{Correspondence to:}

Riaan Rheeder ${ }^{1}$

Email:

riaan.rheeder@nwu.ac.za

Postal address:

PO Box 62, Potchefstroom

2520, South Africa

Dates:

Received: 23 Apr. 2013

Accepted: 15 Oct. 2013

Published: 08 Oct. 2014

How to cite this article: Rheeder, R.A.L., 2014, 'An exploration of synthetic biology: A preliminary Christian ethical assessment of the advantages and disadvantages of synthetic biology', In die Skriflig 48(2), Art. \#722, 10 pages. http:// dx.doi.org/10.4102/ids. v48i2.722

\section{Copyright:}

(C) 2014. The Authors. Licensee: AOSIS OpenJournals. This work is licensed under the Creative Commons Attribution License.
On 20 May 2010, the Venter Institute in America announced that they have fully synthesised the genome of the organism Mycoplasma mycoides whilst in vitro by using a computer connected to a machine that synthesises genes. Thereafter, the genome was placed back into the casing of another organism (Mycoplasma capricolum) and it was reported that the synthesised organism and the genome functioned normally. This synthesised organism was reconstructed to function as a minute little factory with the aim of producing and secreting fuel and medicine something that is not the natural function of this organism. There are certain potential dangers inherent in this kind of technology. Scientists fear that this technology may contaminate or infect humans, animals or the environment, and that it can as such be extremely harmful, or even lead to the destruction of humans. Other scientists are concerned that terrorists can use this technology to kill innocent citizens. Some ethicists are of the opinion that the consequences of synthetic biology is currently unpredictable and that it is therefore risky. In opposition to the potential dangers, one has to mention that synthetic biology indeed can result in far-reaching positive outcomes such as the manufacturing of biofuel and medication. Most scientists and ethicists are of the opinion that the potential dangers involved in synthetic biology should be evaluated in light of the fact that genetic manipulation has not caused any biological devastation over the last 30 years. From a Christian point of departure, the opinion is currently that synthetic biology is not an irresponsible science and technology.

'n Verkenning van sintetiese biologie: 'n Voorlopige Christelik-etiese beoordeling van die voor- en nadele van sintetiese biologie. Op 20 Mei 2010 het die Venter-instituut (in Amerika) aangekondig dat hulle die genoom van die organisme Mycoplasma mycoides ten volle in vitro gesintetiseer het (deur middel van 'n rekenaar, gekoppel aan 'n masjien wat gene sintetiseer). Die berig het verder gelei dat die genoom daarna teruggeplaas is in die omhulsel van ' $n$ ander organisme (Mycoplasma capricolum) - en dat die gesintetiseerde genoom en organisme normaal gefunksioneer het. Hierdie gesintetiseerde organisme word gerekonstrueer om as minuskule fabriek te funksioneer met die doel om brandstof en medisyne te produseer en te sekreer - wat nie die natuurlike funksie van die organisme is nie. Aan hierdie tegnologie is daar ook bepaalde potensiële gevare verbonde. Wetenskaplikes is bang dat hierdie tegnologie mens, dier en omgewing kan kontamineer of infekteer en op dié wyse groot skade kan aanrig - en selfs tot mense se dood kan lei. Ander wetenskaplikes is weer bekommerd dat hierdie tegnologie deur terroriste gebruik kan word om onskuldige burgers dood te maak. Sommige etici is oortuig dat die gevolge van sintetiese biologie tans onvoorspelbaar, en daarom riskant is. Teenoor die potensiële gevare moet gestel word dat sintetiese biologie inderdaad omvangryke positiewe uitkomste soos die vervaardiging van biobrandstof en medisyne tot gevolg kan hê. Meeste wetenskaplikes en etici is van mening dat die potensiële gevare verbonde aan sintetiese biologie beoordeel moet word in die lig van die feit dat genetiese manipulasie in die afgelope 30 jaar geen biologiese ramp veroorsaak het nie. Uit 'n Christelike oogpunt word voorlopig geoordeel dat sintetiese biologie nie 'n onverantwoordelike wetenskap en tegnologie is nie.

\section{Introduction}

In 1999 the Ethics of Genomics Group in America wrote that the ability to synthesise (humanly create) a bacterial genome (chromosome) in vitro 'is still a long way off' due to the great technological gap that had to be bridged at that time (Cho et al. 1999): 'It is not obvious how to achieve this assembly, or even whether we can achieve it.' In addition, there was great doubt whether such a synthesised genome in a bacterial cell will function correctly (Parens, Johnston \& Moses 2009).

On 20 May 2010 the Craig Venter Institute in America announced that they have created the world's first completely self-replicating synthetic genome (in vitro) and that they have placed it 
into the bacterial cell of another species - and that the cell, with its new genome, was functioning normally (Presidential Commission for the Study of Bioethical Issues [Bioethics Commission] 2010). Although genetic manipulation has taken place routinely from about 1974 (Bioethics Commission ibid:38), this breakthrough is unique because all the genetic material needed for bacterial cells to function, was replaced by synthetic genes. This research took about 15 years to become a reality. A large team of researchers were involved at a cost of approximately 40 billion dollars (Bioethics Commission ibid:201).

\section{The description of synthetic biology Introduction}

Before synthetic biology can be assessed in terms of its advantages and disadvantages (aims and impact), it is important to try to ascertain what synthetic biology entails (Rodemeyer 2009; Federal Ethics Committee on Non-Human Biotechnology [ECNH] 2010). This section will pay attention to the concept, procedure and feasibility of synthetic biology.

\section{Ethical question}

The importance of an ethical study and evaluation of synthetic biology is underlined by the fact that, in their report to the American president, the American Bioethics Commission recommended that the government should appropriate funds for the further ethical study of this technology. This ethical preliminary investigation should be completed as soon as possible in order for it to make the most efficient contribution (Bioethics Commission 2010).

Discussion of genetic ethical problems is of crucial importance for the public in general and the church specifically, because it offers a framework within which these ethical problems can be debated (Cho et al. 1999). As many interest groups as possible should be involved in this discussion. When they plead for the involvement of different interest groups, Garfinkel et al. (2008:163) claim that 'little additional rigorous analysis has been done in the last nine years'.

Although this technology has only succeeded on bacterial level, the great ethical question relates to other higher forms of life - and of course humans (Cho et al. 1999; ECNH 2010). ${ }^{1}$ The American Bioethics Commission reports that they have no knowledge of any current or future research program that aims to apply this technology to humans or any other higher species at all. At this stage it is just impossible (see Bioethics Commission 2010).

Although some applications are currently only a vision for the future, the Swiss Bioethical Commission is of the opinion that ethical discussion of this technology is already urgent and relevant (ECNH 2010). Without a doubt synthetic biology brings ethical, religious and social questions to the fore

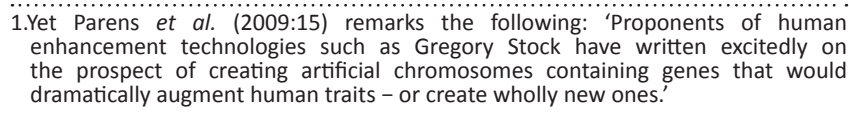
enhancement technologies such as Gregory Stock have written excitedly on the prospect of creating artificial chromosomes containing genes that would dramatically augment human traits - or create wholly new ones.'

(Garfinkel et al. 2008; Rodemeyer 2009). This article should therefore be seen as part of a democratic process through which all academics together search for words inclusively. A good ethical answer is the result of good ethical insight or literacy (see Bioethics Commission 2010).

The ethical discourse and evaluation of synthetic biology divides into two categories. Each of these aspects will be addressed in two separate articles. This article will pay attention to the first category, namely the ethical assessment of the advantages and disadvantages related to synthetic biology (cf. Garfinkel et al. 2008). 'As the process of turning science into technology begins in earnest, the issue of balancing benefits and risks is being raised again' and the process is exacted through 'risk assessment' (see Rodemeyer 2009:7, 11, 24-25). The American Bioethics Commission is also of the opinion that the discussion of the advantages and disadvantages of synthetic biology is important for the ethical evaluation of this technology. According to Parens et al. (2009), the question of advantages and disadvantages linked to an ethical problem is the fundamental ethical question in a democracy. These advantages and disadvantages are not abstract concepts, but can be specified (cf. Bioethics Commission 2010:156, 161). In the assessment of the advantages and disadvantages, one would aim to determine whether this technology is executed with deliberate indifference towards humans, and is therefore applied irresponsibly (ECNH 2010:19). According to Runzheimer and Larsen (2011), the advantages and disadvantages of synthetic biology should be weighed against each other. If the (possible) advantages outweigh the (possible) disadvantages, the technology can be viewed as acceptable.

A second category deals with the question of whether synthetic biology is intrinsically unethical (or unbiblical) and should be prohibited for that reason (cf. Bioethics Commission 2010). The Swiss Bioethical Commission (ECNH 2010) as well as Parens et al. (2009) also suggest this division of categories. They describe the second category of questions as the ethical quest for the correct relationship between man and nature. They also highlight that this matter usually receives less attention. The last-mentioned problem will be evaluated scientifically as a theological-ethical matter in the subsequent article $^{2}$ titled 'Synthetic biology evaluated: The creating God and co-creating human'.

\section{The concept}

Inside the cell nucleus or genome one finds $\mathrm{DNA}^{3}$ molecules. The DNA is the information structure in the cell that determines the functioning (and characteristics) of the cell and ultimately of the organism. The specific order of the

2.It is noteworthy that theologians are consulted regarding bioethical matters worldwide. The American Bioethics Commission approached theologians of different denominations (and religions) for their views (cf. Bioethics Commission 201:137, 155, 175-178): 'Throughout its deliberations, the Commission took special efforts to learn the views of major faith-based communities, including those special efforts to learn the views of major faith-based communities, including those of Christianity, Judaism, and Islam', whilst the Swiss Bioethical Commission state in their report: 'The majority of Committee members are ethicists from the fields of philosophy or theology' (ECNH 2010:3). The reason for this is to hear as many ethical views as possible, with the aim of reaching a thorough ethical evaluation of the bioethical problem.

3.DNA is the acronym for Deoxyribonucleic Acid. 
nucleotide pairs (A, T, G and C) in the DNA determines with exactness what the characteristics of the organism will be. In extreme simplification, a nucleotide order of, for instance TAC, GTG, TGG, CTA, GCA, AAT, TCC, TTA and CGT can determine that a person has red hair and blue eyes. Over the years researchers have succeeded in deciphering the function of most genes as well as other components that regulate the way in which the gene sends signals and exchanges and how they function in an organism. Shortly thereafter scientists also succeeded in building genes with chemical substances in a laboratory. This way the genetic order can be synthesised from the beginning instead of being recombined from different natural sources (Rodemeyer 2009).

Some researchers feel that synthetic biology is just a more powerful version of rDNA (genetic manipulation), a technology that has been applied for 30 years (Rodemeyer 2009). Synthetic biology is the name of a relatively young research field that combines molecular biology, chemistry, computer sciences and engineering. The aim of synthetic biology is the design and construction of functional organisms with the combination of natural or synthetic material (Bioethics Commission 2010; ECNH 2010). Synthetic biology aims to combine genetic material (sequences) with the goal of creating completely new functional organisms. The point of departure of synthetic biology is the art of design with the aim of constructing synthetic organisms that do not exist in nature up to this stage of evolutionary history, regardless of whether the genetic function of the organism is related to natural biology. Although the chemical substances (nucleic acids) that could be synthesised to genes come from biological systems, the design and combination is completely synthetic. 'In essence, synthetic biology will enable the design of "biological systems" in a rational and systematic way' (Rodemeyer 2009:16-17).

Every year the International Genetically Engineered Machine (iGEM) Foundation (http:/ / ung.igem.org) has a competition in which undergraduate students receive the opportunity to design and construct a new biological system by using an existing biological combination (to be found at iGEM's Registry of Standard Biological Parts at partsregistry.org). In 2007 a bacteria was reconstructed to imitate the behaviour and characteristics of a red blood cell, whilst another bacteria was created to find organisms resistant to antibiotics (Rodemeyer 2009). The American Bioethics Commission gives the following preliminary definition of synthetic biology (Bioethics Commission 2010):

A common thread is that synthetic biology is a scientific discipline that relies on chemically synthesized DNA, along with standardized and automatable processes, to address human needs by the creation of organisms with novel or enhanced characteristics or traits. (pp. 46-47)

This technology designs and constructs (synthesises) genetic material in a laboratory from the outset, after which the new genetic material is placed into (another) organism (Rodemeyer 2009). This young field has been driven by the revolutionary view of science and technology, namely that life can be created from lifeless materials (Dabrock 2009). Science can therefore create life from non-living materials. Research from this field is generally careful to give a definition of life. ${ }^{4}$ Due to the complexity and plurality of the concept of life, the concept is been avoided and replaced with the term biological systems (Rodemeyer ibid; ECNH 2010).

\section{Procedure}

Synthetic biology is currently executed with the use of two methods.

The first method is known as the 'framework model' ('chassis' or 'top-down model'). The genome of an existing organism is reduced (under laboratory circumstances) until only that part of the genome remains which is essentially necessary to maintain the organism's basic life and metabolism. Synthetic units are then incorporated into the minimum genome with the aim to execute planned new functions, namely the production of desired substances. Currently this is limited to bacteria and viruses. This is also known as extreme genetic manipulation (ECNH 2010).

The second method is known as the 'Lego model' ('bottomup model') where totally new organisms are created. This is also called absolute synthetic biology (ECNH 2010). This works more or less as graphically illustrated in the Bioethics Commission's report (2010:48).

On 21 May 2010, researchers at the Venter Institute announced that they have successfully designed, synthesised and combined the 1.08 million base pairs of chromosomes of the Mycoplasma mycoides bacteria (Garfinkel et al. 2008; Bioethics Commission 2010).

1. The scientists firstly determined the DNA sequences of the above-mentioned bacteria and keyed it into a computer database in order to digitalise it.

2. Then they gave the computer the command to compile the genetic code (sequences) of the specific bacteria in 1000 base pairs at a time, after which the computer received the command to adapt the code in such a manner that certain characteristics (sequences) were taken away or added. The computer can, for instance receive the command to make one eye blue and the other brown, whilst the hair has to be blonde.

3. Thirdly, this computer, with the genetic codes (sequences), was connected to a DNA synthesising machine, ${ }^{5}$ which received the command to construct about 1080 base pairs of DNA at a time. Around 1000 groups (of 1000 base pairs) are constructed in total, which form the 1.08 million base pairs of the total genome. ${ }^{6}$

4. Thereafter, 10 groups of DNA (of 1000 pairs) are put

4.One exception is Szostak et al. as quoted by ECNH (2010:6) that defines life as follows: 'We can consider life as a property that emerges from the union of two fundamentally different kinds of replicating systems: the informational genome and the three-dimensional structure in which it resides.'

5.A visual example of a DNA synthesising machine (Bioethics Commission 2010:40) Please see Figure 1.

6.The cost currently involved in DNA synthesising is about $\$ 1$ per base pair (Rodemeyer 2009:16; Bioethics Commission 2010:42). 
into a yeast cell, which then form 10000 base pairs. The groups of DNA are added into the yeast cell, where they combine.

5. Lastly, the synthetic genome, which has been recombined and developed in the yeast cell, is removed and planted into another bacterium, Mycoplasma capricolum. The genome of the receiver cell disappeared as the new genome became established, which ultimately resulted in a viable, self-replicating Mycoplasma mycoides cell that only contains synthesised DNA.

In summary, the team synthesised the 1.08 million base pair chromosome of a modified Mycoplasma mycoides genome. The synthetic cell is called Mycoplasma mycoides JCVI-syn1.0 and is the proof of principle that genomes can be designed in the computer, chemically made in the laboratory and transplanted into a recipient cell to produce a new selfreplicating cell, controlled only by the synthetic genome (Synthetic Genomics 2010).

It is important to remark that the specific bacterium Venter built up synthetically is relatively small. At this stage scientists do not yet have the capacity to synthesise the genome of larger organisms (Bioethics Commission 2010).

\section{Feasibility}

Several scientist claim that the execution of synthetic biology will be much more complex than initially suspected (Parens et al. 2009; Rodemeyer 2009). Yet, the current technical problems do not really concern the community of synthetic biologists. Some scientists are of the opinion that the outcomes of synthetic biology will be on the market within the next 10 years (Rodemeyer ibid; Bioethics Commission 2010). However, one should consider that the rate at which synthetic biology will develop in the next few years, would

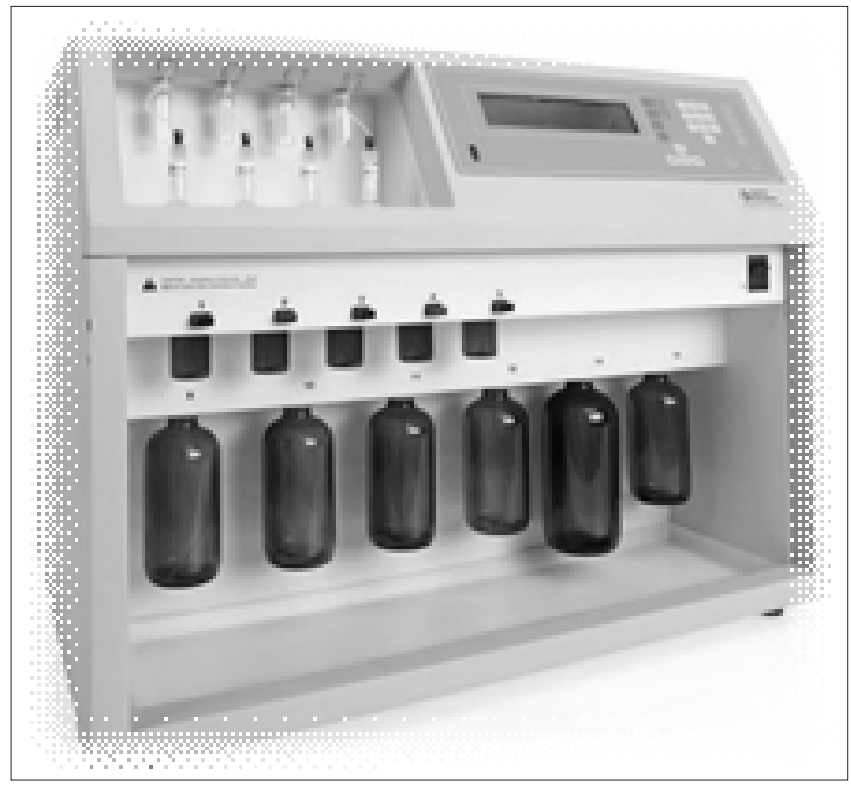

Source: Presidential Commission for the Study of Bioethical Issues (Bioethics Commission) 2010, 'New Directions: The ethics of synthetic biology and emerging technologies', viewed 03 January 2011, from www.bioethics.gov

FIGURE 1: A visual example of a DNA synthesising machine. increase dramatically (Bioethics Commission ibid). The recent history of biotechnology shows that most stumbling blocks can be overcome quickly (Rodemeyer ibid). Parens et al. (ibid:6) writes: 'With synthetic biology, however, scientists hope to leapfrog these problems.' If taken into consideration that Dawkins (2009:325-330) highlights the fact that the skill and knowledge related to genetics will increase exponentially and overwhelmingly in the next 50 years, the application of synthetic biology, even on humans, is not mere futuristic fiction.

\section{Possible advantages of synthetic biology}

\section{Introduction}

The discussion on the advantages of synthetic biology generally refers to two advantages:

1. The first advantage is that synthetic biology is a special method to gain genetic knowledge. Through the use of this technology, the functioning of DNA, cells and organisms can be studied in-depth. The methods can be used effectively to test certain genetic theories (Benner 2008). The newly acquired information can, according to Parens et al. (2009), be further employed to answer the following questions: How does life start?; How does it happen that an array of chemical substances becomes life?; and What is life? (cf. Bioethics Commission 2010).

2. The second fruit that stems from synthetic biology is the capacity to create new products. Parens et al. (2009:7) write: 'Such a synthetic cell could be viewed as a minifactory, producing various substances, from treatments for devastating diseases to weapons of terror.'

Consequently, this article will pay attention to the possible outcomes of synthetic biology that is most generally discussed in literature.

\section{Biofuel Introduction}

Most scientists are of the opinion that synthetic biology will be the first to succeed in the area of biofuel (Parens et al. 2009). Biofuel, in addition to fossil fuel (coal and natural gas), is currently produced from biomass, which comes from plant and animal material as well as organic waste products. Currently, the following materials are used for the production of biofuel: wheat, grass, trees, sugar and maize (Rodemeyer 2009).

\section{Execution}

At the moment biofuel is produced from biomass through a double process. In the first process, the thick cell structures of the cellulose feedstock are broken down, aiming to produce the sugar from which the fuel is produced. This process is, in itself, energy intensive. In a second process, the sugar is converted into fuel. Synthetic biology aims to design and synthesise more powerful organisms (yeast and bacteria) in which the above-mentioned processes can be consolidated in 
one organism for both phases to take place simultaneously.? One such organism is synthesised from the genetic material of several (four or more) other organisms to give it the necessary efficiency for this purpose. This way the production cost of biofuel is drastically reduced (Rodemeyer 2009). ${ }^{8}$

No organism (bacteria, algae or yeast) in nature secretes any kind of fuel. The most advanced form of synthetic biology in the production of biofuel is the development of organisms metabolising sugar (from feedstock) and secreting fuel extremely efficiently. This fuel is highly compatible to a variety of other fuels (petrol, diesel and jet fuel from oil) currently in use (Rodemeyer 2009).

Ethanol is currently the most important biofuel, produced through a fermentation process. Feedstocks such as maize, grass, and wood scobs are used to produce this ethanol (ECNH 2010). Yet, there are problems related to the production of this fuel:

1. Great volumes of corn cobs (or sugar cane or wheat) are needed to make relatively small quantities of ethanol (10 $\mathrm{kg}$ corn gives $4 \mathrm{~L}$ ethanol). The use of large amounts of biomass has a collateral effect on food prices and can lead to food shortages.

2. Ethanol is a product that is very expensive to produce, it in general does damage to storage and transport facilities and it is not the most efficient form of fuel (Rodemeyer 2009).

3. The production of biofuel is also not all that environmentally friendly. Producing $4 \mathrm{~L}$ of ethanol uses $2 \mathrm{~L}$ of fossil fuel (Bioethics Commission 2010). Instead of the (external) fermentation process, synthetically created organisms (yeast, bacteria and algae) are envisioned to secrete the ethanol. These organisms will need less feedstock and energy, whilst they will deliver fuel faster and cheaper. Some fuel produced by such organisms is expected within the next few years (Bioethics Commission ibid). See Figure 2.

Biofuel can also be produced by photosynthetic genetically modified marine algae (Rodemeyer 2009). Synthetic biology has developed a new strategy to reconstruct marine algae cells to continuously secrete oil $^{9}$ (from which biofuel originates) through their cells. This way there is a bigger yield. Some algae was synthetically reconstructed to use sunlight and carbon dioxide as food source (ECNH 2010), and to secrete

7.The basis of our production process is a well-established fermentation process that uses our genetically-engineered yeast strains to convert the sugar source into target molecules such as farnesene' (Amyris n.d.) and 'Pushing the frontiers of synthetic biology and industrial biotechnology, LS9 has perfected an elegant 1-step fermentation process that uses patent-pending DesignerMicrobes ${ }^{T M}$ to efficiently convert renewable feedstocks to a portfolio of "drop in compatible" UltraClean ${ }^{\text {TM }}$ fuels and sustainable chemicals' (REG Life Sciences n.d.).

8.'JBEI researchers in the Fuels Synthesis Division are using the tools of synthetic biology to engineer new microbes as an alternative to yeast that can quickly and efficiently ferment these complex sugars into biofuels, as well as into other valuable chemical products' (Joint BioEnergy Institute n.d.)

9.Bio-oil produced by photosynthetic algae and the resultant biofuel will have molecular structures that are similar to the petroleum and refined products we use today. If successful, bio-oils from photosynthetic algae could be used to manufacture a full range of fuels, including gasoline, diesel fuel and jet fuel, that meet the same specifications as today's products (Synthetic Genomics n.d.).

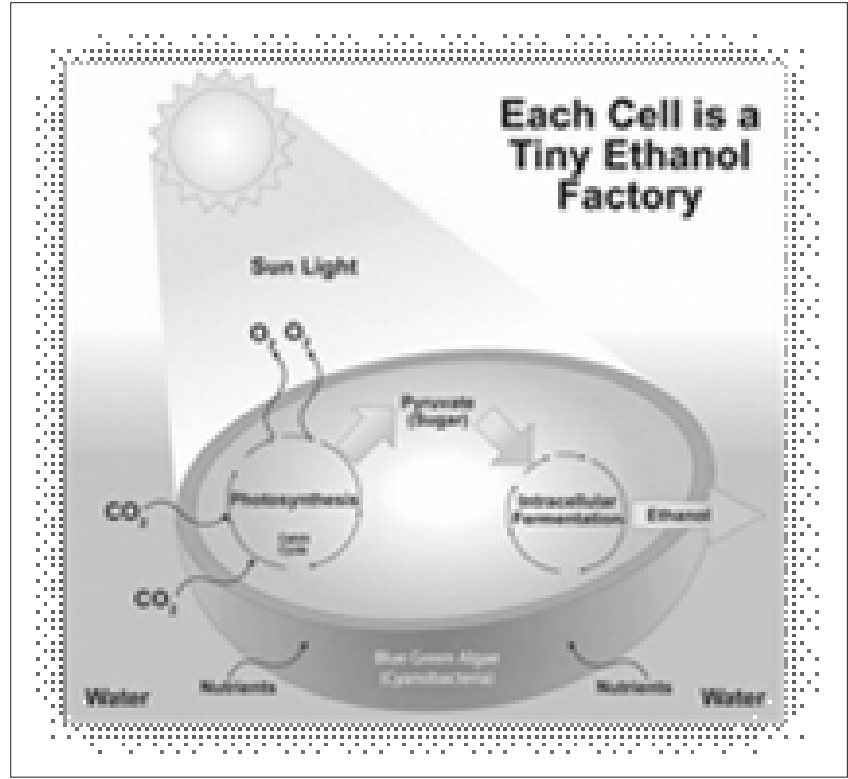

Source: A Green Living, n.d., Home, viewed 05 November 2011, from http:// agreenliving.org/tag/biofuel-production

FIGURE 2: Graphic representation.

fluid (directly in a single step) hydrocarbon and bio-ethanol without interruption. Algae have low input cost, whilst it yields a high percentage of raw materials. Per hectare algae delivers more energy than sugar cane, maize or soya beans. For biofuel production, algae cells are grown, harvested and chemically treated with heat to get to the oil in the cells (Bioethics Commission 2010). ${ }^{10,11}$

Currently, the cheapest way to produce hydrocarbon is to let methane (from gas) react with steam. The possibility of reconstructing the bacteria $E$. coli as well as algae synthetically to get sugar from biomass in a less elaborate manner and to secrete hydrocarbon, is now being investigated. This product is very close to the fuel produced from oil (Rodemeyer 2009). Hydrogen fuel from synthetic organisms will be much cheaper to produce than the current process where it is produced from gas and will need much less storage space (Bioethics Commission 2010). ${ }^{12}$

One more favourable bio-alcohol is butane (Rodemeyer 2009). Some bacteria have built-in enzymes that secrete butane, but the natural process is very slow and does not yield much. With synthetic biology, scientists reconstructed the E. coli bacteria to produce faster and larger quantities of butane..$^{13}$ Butane as raw material is refined to useful fuel and it has the special advantage that it can be used directly in petrol (diesel

10.Unlike competing technologies that utilize micro-organisms to produce ethanol by fermenting sugars from cellulose or other biomass materials, Joule's platform micro-organism is engineered to produce and secrete ethanol in a continuous process, converting more than $90 \%$ of the $\mathrm{CO}$ it consumes directly to end product, with no reliance on biomass feedstocks' (Joule 2011).

11.See Solazyme (n.d.) for a company that is currently working on this possibility.

12.See REG Life Sciences (n.d.) for a company that is currently working on this possibility.

13.'A first major success has been obtained with the bio-production process of isobutene. Subsequently, these enzymes have been integrated in bacteria which were then shown to be able to convert sugar into isobutene in vivo. The conversion yield is now being continuously improved using standard genetically engineering tools' (Global Bioenergies n.d.) 
and jet) engines and it delivers better fuel consumption than ethanol (Rodemeyer ibid; Bioethics Commission 2010). Synthetic biology has also succeeded in reconstructing organisms synthetically to secrete isobutene.

Biodiesel is produced from biomass like sugar cane, vegetable oils, animal fats and reusable restaurant oils. The production cost of biodiesel is very high. Scientists have developed synthetically created organisms (yeast, bacteria [E. coli] and algae) that metabolise plants and secrete diesel directly (Rodemeyer 2009). ${ }^{14}$ This directly secreted diesel floats at the top of the fermentation container and does not need to be distilled or go through some kind of purification process. Some fuels produced by organisms are expected on the market within the next few years (Bioethics Commission 2010). ${ }^{15}$

\section{Medical}

Genetic manipulation technology has been used for 30 years in the manipulation of bacteria with the capacity to produce commercially relevant molecules like insulin or the vaccine against the Hepatitis B virus and the Human Papillomavirus (Parens et al. 2009; Bioethics Commission 2010).

\section{Malaria and cholesterol medication}

One of the best examples of synthetic biology in medicine is the manipulation of an organism with the aim of making the anti-malaria medication artemisinine cheaper and more effective (Garfinkel et al. 2008; ECNH 2010; Bioethics Commission 2010). Malaria affects two to three hundred million people per year and leads to about 1000000 deaths per year in children in sub-Saharan Africa. Artemisinine is a chemical substance that comes from the plant Artemisia. Artemisinine is an effective cure, but difficult to obtain due to the limited production and high cost (Parens et al. 2009). Synthetic biologists of the University of California have reconstructed the E. coli bacteria to secrete high volumes of the forerunner, which can quickly be converted into artemisinine. If it is successful, synthetic biology can decrease the cost drastically and this can increase the supply worldwide (Bioethics Commission ibid). The Keasling Laboratory (in America) has already synthesised a bacterium (and yeast) that produces the medicine artemisinine (Parens et al. ibid). Researchers currently build organisms that can secrete the cholesterol medication atorvastatin (Lipitor ${ }^{\circledR}$ ). This will also be a cheaper process. Currently, artemisinine and atorvastatin are the only products that have realised commercially (ECNH ibid).

\section{Vaccines}

Synthetic biology techniques are also used with the aim of developing vaccines. Companies currently have to rely on the WHO to identify the strains of viruses as well as for the provision of live reference viruses with the aim on developing seasonal or pandemic vaccines. Companies in America are 14.For an example of organisms that secrete oil, see Amyris (n.d.).

15.See Amyris (n.d.) for a company that is currently working on this possibility. busy to develop a virus bank containing the seed strains of synthetically created virus types that can, after the necessary changes, be used for the production of vaccines promptly. It will therefore not be necessary to wait for live viruses from the WHO any longer (Bioethics Commission 2010).

\section{Finding and treating sick cells}

Synthetic biologists are currently experimenting with synthesising gene combinations (nucleotide) which are not found in nature. Bacteria and T-cells can be built to circulate in the body with the aim of finding sick cells and treating them (ECNH 2010). In this manner, scientists have developed diagnostic tests with specific nucleotide sequences that can test a person for the HIV-virus, cystic fibrosis and other diseases (Rodemeyer 2009). There are currently experiments with the synthetic creation of genetic combinations that can find specific cancerous tumours (based on genetic markers). Regarding the last-mentioned: when a synthesised genetic combination (an organism) is used as treatment, it will be able to target the tumour more specifically to destroy it (Parens et al. 2009), without destroying the healthy cells (Bioethics Commission 2010).

\section{Food, environment and military use High-yield and disease resistant plants}

In addition to rDNA and cloning, synthetic biologists experiment with the creation of high-yield and disease resistant plants. Furthermore, these manipulated plants can be provided with synthetic microorganisms that help with more effective nutrition, and it can lower water and fertilizer usage. Synthetic biologists reconstruct the (genetic) characteristics of plants by using metabolic components of other plants to cultivate plants with higher protein content (Bioethics Commission 2010).

\section{Biosensors}

There is also an effort to create a microbial group, known as synthetic biofilms, which can be used as environmental biosensors. These sensors are used to monitor soil for nutritional quality and soil degradation (Bioethics Commission ibid), whilst other synthetic organisms are being created to act as microbial herbicides (Rodemeyer 2009). Some bacteria have the ability to determine whether there is arsenic in the soil (Parens et al. 2009).

\section{Pollution}

Synthetic biology is furthermore used to develop organisms (for instance Pseudomonas) that decrease pollution - and even reverse it (Parens et al. 2009; Rodemeyer 2009). The way in which organisms that naturally occur, devoured the oil spill on the American coast in 2010 showed how effectively such organisms can be used. Organisms are being developed to metabolise chemical and toxic pollution like oil, industrial refrigeration substances and solutants, explosives, waste products of burnt oil, coal and tar (Parens et al. ibid; Bioethics Commission 2010). Carbon dioxide $\left(\mathrm{CO}_{2}\right)$ absorbing bacteria can be developed with the aim of decreasing atmospheric 
carbon dioxide levels (Parens et al. ibid; Rodemeyer ibid; ECNH 2010).

Synthetic biology can be used for the development of new biological weapons (Parens et al. 2009), or the creation of biological weapons to fight bioterrorism (ECNH 2010).

\section{Summary}

From the above-mentioned discussion, it is clear that there are powerful potential advantages to synthetic biology. At the moment it seems as if the highest potential of this technology lies on the terrain of biofuel and medicine.

\section{Possible disadvantages of synthetic biology Introduction}

In addition to the advantages stated above, one also finds that literature refers to a variety of potential disadvantages of synthetic biology. Parens et al. (2009) here distinguish further between possible physical disadvantages and non-physical disadvantages, but mention that the conceptualisation and identification of non-physical disadvantages have not been completed. For this reason, this article will mainly pay attention to the physical disadvantages.

\section{Unpredictable}

According to the Bioethics Commission (2010), ‘ $[m]$ any potential applications of synthetic biology go well beyond the genetic engineering practiced throughout the biotechnology industry today', which means that a totally new (de novo) complex organism can be created of which the specific genetic combination has never before existed in history. There is a concern that the creation of such organisms can result in certain unpredictable functions (emerging properties), characteristics and synergistic interactions with unknown results. It is very difficult to assess new entities beforehand, because they have no evolutionary or ecological history, or they are composed from different independent sources. Researchers have the ability to predict the outcomes of smaller genetic changes, because they have knowledge of similar genetic components in the original organism. This way researchers have assessed the disadvantages and dangers related to genetically manipulated organisms reasonable accurately (Rodemeyer 2009). Scientists cannot predict the possible results for humans or the environment (cf. Rodemeyer ibid; Bioethics Commission 2010). This type of danger is known as the 'unknown unknowns' (Parens et al. 2009).

The ability of the organisms to mutate and evolve begs questions regarding the placement of organisms in a natural environment where there is selective pressure. The possibility of evolving creates additional uncertainty, because the evolution is, per definition, unpredictable - now and in the distant future. In addition, Rodemeyer (2009) also feels that American scientists have little experience of the evolutional potential of organisms, since almost no genetically manipulated microorganisms have ever been placed into an uncontained environment, because researchers have struggled to establish functioning populations of microorganisms (Bioethics Commission 2010).

\section{Accidental contamination}

\section{Enclosed environments (humans)}

Contamination by means of an accident (biosafety), during the releasing of some synthetic organisms, is seen as the main danger related to this technology (Garfinkel et al. 2008; Parens et al. 2009). Risk occurs when the organisms escape from an enclosed situation like an academic or industrial laboratory or from an enclosed industrial environment where the final product is manufactured (Garfinkel et al. ibid; Rodemeyer 2009). One should keep in mind that these organisms have the ability to reproduce quickly, to evolve (change) and to spread (Rodemeyer ibid; Bioethics Commission 2010). If the organism is, or becomes, pathogenic, diseases can spread to laboratory researchers and workers with, for instance a needle prick, or transferring by air. In this way, infection or disease can spread to the neighbouring and broader community (Rodemeyer ibid; Bioethics Commission ibid).

\section{Unenclosed environment (nature)}

The possibility also exists that synthetic organisms meant for use in unenclosed environments can have risks and dangers. A hypothetical possibility is the dangerous scenario where a newly manipulated, highly productive (blue-green) alga that has been developed for fuel production, accidentally spills from the reservoir and starts to supplant the natural algae (Bioethics Commission 2010). In addition to this, powerful synthetic organisms (yeast and bacteria) that break down biomass (sugar cane, wheat and cellulose) faster and more efficiently to components that will yield energy easier, may spill from the fermentation reservoirs (Rodemeyer 2009). Different from organisms in an enclosed environment, these organisms will be manipulated to survive and function in a natural environment, which would probably mean that they would be able to reproduce faster, to spread and to evolve. The possible dangers related to spilling such an organism are the following (Rodemeyer ibid; Bioethics Commission ibid):

- Organisms can spread to natural water environments and have interaction with natural organisms - with the result that other species are supplanted and/or infected.

- Synthetic organisms can infect plants and animals in the environment.

- The ecosystem can be deprived of crucial nutritional elements that will have far-reaching negative results for the environment.

- The ecological balance in a certain living system can be disturbed.

- When such an organism finds an ecological niche, it will be very difficult to remove or eradicate the organism.

- Genetic characteristics of the synthetic organisms can be transferred to natural organisms via the genetic flow, with the result that undesired genetic characteristics or artificial characteristics are transferred to nature. ${ }^{16}$

16.In 1999 it was reported that the pollen of maize plants that have been genetically manipulated to secrete weed-killing proteins (Bacillus thuringiensis) also killed some animal species. In 2002 it was reported that maize, which was genetically manipulated to produce a protein used in a vaccine for pigs, was accidentally mixe with soya beans for human consumption. In 2006 it was reported that rice farmers in America found that their rice seed was contaminated with a non-approved genetically manipulated variant (Rodemeyer 2009:47-48). 


\section{Intentional contamination \\ Malice}

Contamination by means of intentional release (biosecurity) of these synthetic organisms can also occur (Garfinkel et al. 2008; Rodemeyer 2009). Organisms can also be released during illegitimate handling, for example when a scientist with ill will changes jobs and takes the organisms to the new work environment. Laboratories can also be run unprofessionally (garage laboratories), which increases the risk (ECNH 2010).

\section{Bioterrorism}

One of the most discussed and feared possibilities of synthetic biology is when this technology is used for the creation of extremely dangerous pathogens by terrorists or instance Cho et al. 1999; Rodemeyer 2009). Synthetic biology can build extremely dangerous bacteria in a relatively easy manner (ECNH 2010). This fear was incited by the fact that scientists who work in the field of rDNA succeeded in reconstructing the poliovirus (in 2002), the Mycoplasma genome and the 1918 flu virus in a laboratory in 2005; (Rodemeyer ibid; Bioethics Commission 2010). These examples show that concern about the intentional abuse of these organisms is not unfounded (Rodemeyer ibid). One should also keep in mind that there has been a huge rise in commercial DNA-synthesising companies (and therefore knowledge) that can build and sell specific DNA sequences on demand (Rodemeyer ibid). It is also clear that it will in future become increasingly easier to overcome the financial and technical problems (ECNH 2010).

\section{Fairness and available land}

This section will shortly address some potential non-physical disadvantages. Some critics of synthetic biology and its application are of the opinion that this technology will only increase an unfair technological gap between the industrial and developing countries (ECNH 2010).

Another danger is the creation of powerful organisms (yeasts and bacteria) that break down biomass fast and efficiently, which can lead to the destruction of large ecosystems, because so much agricultural land will be needed. The cultivation of large quantities of feedstocks for biofuel can influence food prices and security negatively to a serious degree (Bioethics Commission 2010; ECNH 2010).

\section{Preliminary ethical assessment Advantages assessed}

Firstly, environmentally friendly fuel and antimalaria medication (and other medical possibilities) serve as examples of how synthetic biology can be to the advantage of the entire society and can promote welfare this way. For this reason, research in this regard should be encouraged and made possible (Bioethics Commission 2010; see sections 3.1-3.4).

Secondly, synthetic biology can bring economic advantages through job creation. In the year 2006, the bio-industry in America generated an income of about $\$ 59$ billion
(Rodemeyer 2009). The potential economic impact of synthetic biology on job creation and economic growth is difficult to predict, but the American Bioethics Commission claims that the chemical industry alone generates a global income of R2 trillion and can result in about 1.2 million job opportunities. Economic opportunities that are created by this technology can especially be of value for developing countries - if this technology is expanded to the third world (Bioethics Commission 2010).

Thirdly, intellectual freedom is the heart of research and scientific knowledge. Intellectual freedom is essential within the academic environment. This means that scientists should receive the opportunity and capacity to investigate ideas openly and freely, even controversial and unpopular ideas. This opportunity and ability forms the foundation of education and research. ${ }^{17}$ Academic freedom does not imply socially irresponsible behaviour or any research that holds danger for the community or institutional environments without any protection. Several scientists at universities do research in synthetic biology and should, within the above understanding of intellectual freedom, not be blocked. One can therefore agree with the American Bioethics Commission (2010:12) when they claim: 'A moratorium at this time on synthetic biology research generally or in particular areas would inappropriately limit intellectual freedom.'

\section{Disadvantages assessed}

Firstly, it has been indicated that de novo organisms are created of which the risks are difficult to predict. Rodemeyer (2009) feels that it is highly improbable that a synthetic microorganism that has been compiled from different nonpathogenic sources will develop pathogenity, although the possibility is perhaps not excluded. ${ }^{18}$ In addition to this, it should be kept in mind that biological research has had risk throughout history. As an example, one can refer to Edward Jenner's experiments 200 years ago. He developed a vaccine against pox with the use of live cowpox viruses. The study of pathogenic organisms, if they are released, can infect thousands of people and even kill them, but unfortunately there is no other way. 'In any scientific inquiry, risks must be justified by anticipated benefits' (Bioethics Commission 2010:124).

It has already been indicated that synthetic biology has the potential danger of contamination. One of the 'advantages' of synthetic biology, in the second place, is that different procedures are developed to prevent such possible dangers. The preventative measures that are being developed include the so-called 'eliminator-gene' or

17.A verdict by an American judge in 1957 (Justice Warren in Sweezey vs. New Hampshire, 354 US. 234; cf. Bioethics Commission 2010): 'No field of education is so thoroughly comprehended by man that new discoveries cannot yet be made [...] Scholarship cannot flourish in an atmosphere of suspicion and distrust. Teachers and students must always remain free to inquire, to study and to evaluate, to gain

18.Rodemeyer (2009:28) highlights a single documented case where researchers adapted a mouse poxvirus genetically to give expression to a certain protein with the intention to make mice infertile. The modification in the virus made the harmless poxvirus malignant, with the result that immunised mice died. 
'suicide' switches built into these organisms to prevent them from multiplying (procreating) when they move outside of the enclosed environment. Organisms can be manipulated in such a manner that they need certain nutritional substances not available outside the laboratory or in the absence of a specific chemical environment they are prohibited from surviving (Bioethics Commission 2010; ECNH 2010). Thirty years of genetic manipulation proves that these manipulated organisms' ability to live outside an artificial environment is not very good (Garfinkel et al. 2008; Rodemeyer 2009; Bioethics Commission ibid) - simply because they have a weaker capacity to compete with the natural ecosystem (ECNH ibid). Several researchers are of the opinion that it is improbable that these organisms will procreate effectively in nature (Rodemeyer ibid). In addition to this, researchers also noted that when synthetic organisms are allowed to develop in the laboratory, they constantly evolve to non-functionality, which means they get rid of their manipulated characteristics (Rodemeyer ibid; Bioethics Commission ibid).

Parens et al. $(2009: 9,28)$ are of the opinion that, during an assessment of synthetic biology, one should seriously consider the experiences with technology related to synthetic biology such as genetic manipulation. Synthetic biology finds itself in a similar position as genetic manipulation in the 1970s (Bioethics Commission 2010). According to Rodemeyer (2009), one of the strongest arguments against a hasty dismissal of synthetic biology based on the possible disadvantages, is the fact that rDNA is similar to synthetic biology, and it did not cause any disastrous event in the last 35 years of its existence. The editorial board of the scientific journal Nature (Anon. 2004) makes the following relevant remark:

At the same time, biologists have come to feel increasingly secure in the belief that some ecological nightmare is not likely to spring out of a graduate student's Petri dish. Every day for decades they have been transferring modified genes into microbes, nematodes and mice. At least some of the results - the errant fruit fly or the culture tube spilled in the sink - have no doubt escaped into the environment, without producing a biological Chernobyl. (p. 613)

It should also be considered that different valuable biotechnical products, both in medicine and agriculture, have been developed and commercialised successfully without any remarkable health or environmental problems. About 200 new therapies and vaccines have been commercialised by biotechnology, whilst in agriculture several pest-resistant and herbicide-tolerant wheat, soya beans, cotton and canola have been developed with great success. Currently the safety record is really comforting. In addition, the American authorities (USDA; EPA) approved thousands of applications for experiments with genetically manipulated microorganisms in non-enclosed environments (Rodemeyer 2009).

The fact that the evolution of organisms is a possibility should be kept in mind. Yet, this possibility should at this stage be judged in light of the special safety that accompanies genetic manipulation. Scientists are well aware of the fact that evolution has the capacity to make an organism lose its manipulated characteristics. They are therefore working hard on methods to keep the organism stable for several generations for it to be able to do its work (cf. Rodemeyer 2009).

Thirdly, when considered in conjunction with the arguments offered above, one can argue against the danger of bioterrorism, because in spite of the fact that the public has access to genetic combinations, it is not enough to create dangerous organisms. The necessary host and very specific and complex circumstances are needed for the execution of synthetic biology. Very few individuals or groups, known as the 'DIY community', (currently) have the financial or technical ability to realise this possibility. Therefore the potential is quite low (Bioethics Commission 2010). One should also keep in mind that, as with any other national threats, the government has an important role to fulfil in the protection of any useful but dangerous products (ECNH 2010).

In answer to the argument that this technology is unfair towards the developing countries, it can also be argued that national sovereignty implies that the technologically advanced countries have the right to technological development. However, these countries have the moral obligation to help developing countries in the development of their technical knowledge (ECNH 2010). It should also be considered that the development of this technology can also bring great financial benefit to developing countries.

Fifthly, the argument that synthetic biology will place immense pressure on available land, with the ecological implications thereof, can be responded on by stating that researchers are already synthesising organisms with special digestive systems that can digest the complex starch, known as cellulose and found in many grasses, shrubs and trees, effectively. These plants are not used for food and therefore it will not have an influence on food prices and security. It also means that less additional land will be needed for the cultivation of field crops (Rodemeyer 2009; Bioethics Commission 2010).

\section{Christian assessment}

Although the opinion existed that synthetic biology should continue carefully and with supervision, it is still important that the possible dangers should be considered in earnest and that the necessary precautions should be taken. Synthetic biology should be guided by active supervision as a form of stewardship. According to Douma (1997), stewardship means that God gives humans the mandate to rule this world as his representatives. An important part of this stewardship is the fact that humans should act protectively towards fellow humans. Stewardship includes laboratory safety as well as the safe transport and storage of dangerous organisms. These measures should be supplemented by the involvement of government and non-governmental organisations (the industry), whilst supervision should 
be submitted to continuous public dialogue. All the different parties involved, should be coordinated (Bioethics Commission 2010; ECNH 2010). A culture of responsible stewardship should be promoted (Bioethics Commission ibid; Rodemeyer 2009), which means that researchers who work with these potentially dangerous organisms should receive training in research ethics to guide their knowledge on biosafety and security.

No Christian may have peace with negligence and intentional mistakes. A Christian's view of humans and God does not tolerate that. The Christian knows that every person is a creation of God (Ps 8:5), and has been created in the image of God (Gn 1:28). Therefore, every person should be treated and viewed with dignity (Van Wyk 1998). It would be a transgression of the sixth commandment (Ex 20:13; Heidelberg Catechism Q\&A 105) if synthetic biologists or the synthetic biology industry, endanger their own lives or the lives of others, or cause detriment to people with the irresponsible execution of technology (De Bruyn 1993), since no person may harm another by his actions ( $\mathrm{Rm} 13: 10)$. Christians know that they should love their fellow beings and may not place any person in danger (Mt 7:12). God demands that damage to our fellow humans should be prevented as far as possible (Ex 23:5; Heidelberg Catechism Q\&A 107, 111).

Theological-ethically a distinction can be made between exposing someone to danger and surrendering the person to danger (cf. Douma 1992). This distinction can be illustrated by using the example of a vehicle. Using a vehicle exposes one to danger, although most people reach their destinations safely as a rule. Psalm 91 shows that people's lives are always exposed to danger. However, when someone drives recklessly or under the influence of alcohol, he exposes others to danger wilfully, which means that the chance that others will be disadvantaged or endangered is much larger or even certain. Although science always carries the potential of unintentional and unforeseen accidents (i.e. exposure to danger), in light of the above ethical assessment from a Christian point of view, one can judge that synthetic biology (currently) does not constitute a negligent science and technology, because the technology does not (currently) expose people to danger wilfully.

\section{Conclusion}

It is interesting that the well-known molecular biologist Richard Dawkins (2009:304) says the following: 'I am undecided about the politics of GM foods, torn between the potential benefits to agriculture on the one hand and the precautionary instincts on the other.' In contradiction to this caution, one can in light of the above ethical assessment agree with Parens et al. (2009) when they judge that ' $[d]$ ismissal is premature'. One can agree with the conclusion of the American Bioethics Commission (2010) when they argue that:

While the Commission did not observe significant religious concerns related to synthetic biology at this time, the field is young, and future developments may prompt new concerns, underscoring the importance of ongoing deliberation that is responsive to changing circumstances in science and society. (p. 155)

At this stage, the advantages of synthetic biology outweigh the potential disadvantages or dangers.

\section{Acknowledgements Competing interests}

The author declares that he has no financial or personal relationship(s) that may have inappropriately influenced him in writing this article.

\section{References}

A Green Living, n.d., Home, viewed 05 November 2011, from http://agreenliving.org/ tag/biofuel-production

Amyris, n.d., Home, viewed 05 November 2011, from http://www.amyris.com/

Anon., 2004, 'Editorial: Futures of artificial life', Nature 431 (7009), 613. http://dx.doi. org/10.1038/431613b

Benner, S.A., 2008, 'Biology from the bottom up', Nature 452 (10), 692-694. http:// dx.doi.org/10.1038/452692a

Cho, M.K., Magnus, D., Caplan, A.L., Mcgee D. \& The Ethics of Genomics Group, 1999 'Ethical considerations in synthesizing a minimal genome', Science 286, 2087-2090. $\mathrm{http}: / / \mathrm{dx}$.doi.org/10.1126/science.286.5447.2087

Dabrock, P., 2009, 'Playing God? Synthetic biology as theological and ethical challenge', Systems and Synthetic Biology 3, 47-54. http://dx.doi.org/10.1007/s11693-0099028-5

De Bruyn, P.J., 1993, The ten commandments, Varia Publishers, Midrand.

Douma, J., 1992, De Tien Geboden: Handreiking voor het Christelijk leven, Uitgeverij Van den Berg, Kampen.

Douma, J., 1997, Medische Ethiek, Kok Uitgeverij, Kampen.

Dawkins, R., 2009, The greatest show on earth: The evidence for evolution, Transworld Publishers, London.

Federal Ethics Committee on Non-Human Biotechnology (ECNH), 2010, 'Synthetic Biology - Ethical Considerations: Report of the ECNH', viewed 05 November 2011 from www.ekah.admin.ch

Garfinkel, M.S., Endy, D., Epstein, G.L. \& Friedman, R.M., 2008, 'Synthetic biology', in M. Crowley (ed.), From birth to death and bench to clinic: The Hastings Center bioethics briefing book for journalists, policymakers, and campaigns, pp. 163-168, The Hastings Center, New York.

Global Bioenergies, n.d., A gas fermentation process that overcomes present limitations, viewed 05 November 2011, from http://www.global-bioenergies.com/index. php?option=com_content\&view $=$ article\&id $=66 \&$ Itemid $=164 \&$ lang $=e n$

International Genetically Engineered Machine (iGEM) Foundation, n.d., Main Page, viewed 03 January 2011, from http://ung.igem.org

Joint BioEnergy Institute, n.d., Fuels synthesis, viewed 05 November 2011, from http:// www.jbei.org/research/divisions/fuels-synthesis/

Joule, 2011, Joule awarded patents for high volume ethanol production from sunlight and CO2, viewed 5 November 2011, from http://www.jouleunlimited.com/ news/2011/joule-awarded-patents-high-volume-ethanol-production-sunlight-and$\mathrm{CO} 2$

Parens, E., Johnston, J. \& Moses, J., 2009, 'Ethical issues in synthetic biology: An overview of the debates', Woodrow Wilson International Center for Scholars, New York, Garrison, The Hastings Center.

Presidential Commission for the Study of Bioethical Issues (Bioethics Commission), 2010, 'New Directions: The ethics of synthetic biology and emerging technologies', viewed 03 January 2011, from www.bioethics.gov

REG Life Sciences, n.d., Home, viewed 03 January 2011, from http://www.ls9.com/ technology

Registry of Standard Biological Parts, n.d., The Registry's Repository - iGEM, viewed 05 November 2011, from partsregistry.org

Rodemeyer, M., 2009, New life, old bottles: Regulating first-generation products of synthetic biology. Synthetic biology project, Woodrow Wilson International Center for Scholars, The Hastings Center, Garrison, NY.

Runzheimer, J. \& Larsen, L.J., 2011, Medical ethics for dummies, Wiley Publishing Inc., Indianapolis. (Kindle edn.)

Solazyme, n.d., Home, viewed 29 January 2014, from http://solazyme.com/

Synthetic Genomics, 2010, Press Release: October 7, 2010, viewed 03 January 2011, from http://www.syntheticgenomics.com/media/press/100710.html

Synthetic Genomics, n.d., Next generation Algal Biofuels fact sheet: Alliance between Synthetic Genomics Inc and ExxonMobil Research and Engineering Company, viewed 03 January 2011, from http://www.syntheticgenomics.com/media/ emrefact.html

Van Wyk, J.H., 1998, Etiek in eenvoud. Gesprekke oor morele vraagstukke, Potchefstroomse Teologiese Publikasies, Potchefstroom. 